\title{
TREEFALLS AND PATTERNS OF UNDERSTORY SPECIES IN A WET LOWLAND TROPICAL FOREST ${ }^{1}$
}

\author{
Patricia Richards \\ Department of Zoology, University of Michigan, Ann Arbor, Michigan 48104 USA \\ G. Bruce Williamson ${ }^{2}$ \\ Department of Zoology, Indiana University, Bloomington, Indiana 47401 USA
}

\begin{abstract}
Nested quadrats were used to determine natural clump sizes for three understory species in a mature, wet, tropical forest in Costa Rica. Under a closed canopy, individuals $>60 \mathrm{~cm}$ tall of the understory palm Cryosophila guagara are shown to clump maximally at a size which corresponds to the size of lightgaps created by fallen canopy trees, suggesting that the distribution pattern of this palm is related to the pattern of fallen trees. Two other understory species, Neonicholsonia watsonii and Carludovica palmata, clump maximally at sizes which do not correspond to the sizes of average canopy gaps.
\end{abstract}

Key words: Carludovica palmata; clumping, palms; Costa Rica; Cryosophila guagara; distribution pattern, Cryosophila guagara; lightgaps; Neonicholsonia watsonii; palms; treefall pattern; tropical forest.

\section{INTRODUCTION}

Numerous studies in recent years have demonstrated that most plant species are not randomly distributed. In an extensive review of the subject, Kershaw (1963) emphasizes the need to determine the scale of clumping as a first step in the elucidation of the causal factors involved. He cites examples of clumping produced by species morphology, environmental discontinuities and inter- and intraspecific interactions. Schulz (1960) stresses the importance of lightgaps of different sizes in maintaining light-requiring secondary forest species (the "nomads" of van Steenis 1956), and Jones (1945) suggests that mature forests may be mosaics of patches of even-aged groups, noting that lightgaps large enough to allow regeneration could serve to maintain such a pattern. Similar suggestions have been made by Aubréville (1938) and Richards (1964), although these authors were unable to present conclusive evidence to support this hypothesis. The size of lightgaps caused by fallen canopy trees has recently been shown to determine the distribution pattern of adults of early seral stages within a temperate beech-maple forest (Williamson 1975). This paper presents the results of a study designed to determine the possible effects of treefalls in a mature, wet lowland tropical forest on the distribution pattern of various size classes of two small palms (Cryosophila guagara and Neonicholsonia watsonii) and one member of the Cyclanthaceae (Carludovica palmata). Taxonomic descriptions of

${ }^{1}$ Manuscript received 13 March 1974; accepted 1 April 1975.

${ }^{2}$ Present address: Department of Biology, University of South Florida, Tampa, Florida 33620 USA. these species can be found in Allen (1956) for the two palms, and in Harling (1954) for Carludovica palmata.

\section{METHODS}

Five lightgaps caused by treefalls were selected for study in an Osa Terminalia forest (Holdridge 1971) on the Peninsula de Osa, Costa Rica. The treefalls varied in size and in the orientation of the fallen trunk, and all the gaps were caused by the fall of entire trees. In order to determine the relative densities of species at different points along the length of the fallen tree, a longitudinal axis was drawn parallel to the trunk and five 2-m wide transects were set out at regular intervals perpendicular to this axis and extending to the edge of the clearing. Transects were numbered consecutively from 1 to 5 , from the root end to the crown end of the fallen tree. All individuals $>60 \mathrm{~cm}$ in height were recorded, and density was calculated for each transect. Single stems were counted in the case of the two palms, single petioles in the case of $C$. palmata. This method is appropriate for recording the single-stemmed individuals of the two palms, but is somewhat arbitrary for the acaulescent $C$. palmata.

Each gap was mapped and measured. The point of first branching of the fallen tree was recorded and served to define the boundary between the trunk and crown portions of the gap.

In order to determine scales of clumping in an area with a closed canopy, a $51 \times 51-\mathrm{m}$ plot was selected in an adjacent part of the forest. The plot was chosen because it contained no large canopy gaps. All individuals of Cryosophila guagara, $N$. watsonii, and Carludovica palmata $>60 \mathrm{~cm}$ in height 
Table 1. Densities (individuals $/ \mathrm{m}^{2}$ ) in 5 transects perpendicular to the lognitudinal axis of the fallen trunk for 5 treefalls. Transects grade from the roots (transect no. 1) to the crown (transect no. 5) of the fallen trees

\begin{tabular}{|c|c|c|c|c|c|c|c|c|c|c|c|c|c|c|c|}
\hline \multirow{2}{*}{$\begin{array}{c}\text { Treefall } \\
\text { no. }\end{array}$} & \multicolumn{5}{|c|}{$\begin{array}{c}\text { Cryosophila guagara } \\
\text { Transect no. }\end{array}$} & \multicolumn{5}{|c|}{$\begin{array}{c}\text { Neonicholsonia watsonii } \\
\text { Transect no. }\end{array}$} & \multicolumn{5}{|c|}{$\begin{array}{l}\text { Carludovica palmata } \\
\text { Transect no. }\end{array}$} \\
\hline & 1 & 2 & 3 & 4 & 5 & 1 & 2 & 3 & 4 & 5 & 1 & 2 & 3 & 4 & 5 \\
\hline $\begin{array}{l}1 \\
2 \\
3 \\
4 \\
5\end{array}$ & $\begin{array}{l}0.07 \\
0.28 \\
0.17 \\
0.18 \\
0.21\end{array}$ & $\begin{array}{l}0.30 \\
0.15 \\
0.10 \\
0.16 \\
0.23\end{array}$ & $\begin{array}{l}0.02 \\
0.15 \\
0.08 \\
0.14 \\
0.06\end{array}$ & $\begin{array}{l}0.07 \\
0.00 \\
0.05 \\
0.11 \\
0.04\end{array}$ & $\begin{array}{l}0.00 \\
0.00 \\
0.03 \\
0.00 \\
0.04\end{array}$ & $\begin{array}{l}0.10 \\
0.03 \\
0.37 \\
0.03 \\
0.13\end{array}$ & $\begin{array}{l}0.13 \\
0.03 \\
0.17 \\
0.18 \\
0.04\end{array}$ & $\begin{array}{l}0.08 \\
0.00 \\
0.10 \\
0.19 \\
0.00\end{array}$ & $\begin{array}{l}0.12 \\
0.00 \\
0.03 \\
0.17 \\
0.04\end{array}$ & $\begin{array}{l}0.00 \\
0.00 \\
0.03 \\
0.04 \\
0.05\end{array}$ & $\begin{array}{l}0.00 \\
0.00 \\
0.00 \\
0.87 \\
0.08\end{array}$ & $\begin{array}{l}0.00 \\
0.00 \\
0.00 \\
0.00 \\
0.00\end{array}$ & $\begin{array}{l}0.00 \\
0.00 \\
0.00 \\
0.00 \\
0.03\end{array}$ & $\begin{array}{l}0.00 \\
0.00 \\
0.00 \\
0.08 \\
0.00\end{array}$ & $\begin{array}{l}0.00 \\
0.00 \\
0.00 \\
0.27 \\
0.39\end{array}$ \\
\hline Mean density & 0.18 & 0.19 & 0.09 & 0.05 & 0.01 & 0.13 & 0.11 & 0.07 & 0.07 & 0.02 & 0.19 & 0.00 & 0.01 & 0.01 & 0.13 \\
\hline
\end{tabular}

were recorded for 289 contiguous quadrats within this plot, each quadrat being $3 \times 3 \mathrm{~m}$. The purpose of this mapping procedure was to permit a nested quadrat analysis for estimating the scale of clumping for the three species. The quadrat units were combined into successively larger blocks and a clumping measure was computed for each block size.

The scale of clumping was estimated using Morisita's (1959) index. This method is a significant improvement on the contiguous quadrat analysis proposed by Grieg-Smith (1952) because the index is independent of the number of individuals when the pattern is random or clumped (Pielou 1969). Morisita's index $\left(I_{\delta}\right)$ is given by

$$
I_{\delta}=q \sum_{i=1}^{q} n_{i}\left(n_{i}-1\right) / N(N-1)
$$

where $q$ is the number of quadrats, $n_{i}$ is the number of individuals of the species in the $i$ th quadrat, and $N$ is the total number of individuals in all quadrats. The index was computed for the three species for quadrats of increasing size, from 1 unit by 1 unit (units are $3 \mathrm{~m}$ ) to 17 units by 17 units, with quadrat size increments of 1 unit. The value of $I_{\delta}$ equals 1.0 when the species is randomly distributed, where random implies the independent assortment of individuals into quadrats with an equiprobability of each individual entering any quadrat. If the individuals are clumped, $I_{\delta}$ is $>1.0$; if the individuals are evenly distributed, $I_{\delta}$ is $<1.0$. The measure increases monotonically with increases in clumping. For a species in a given area, the values of $\boldsymbol{I}_{\delta}$ calculated for various quadrat sizes permit the identification of the sizes at which clumping is maximal, and thereby suggest the sizes of the natural patches for a given species (Morisita 1959).

\section{Results And Discussion}

The density values of the three species in each of the five transects of the five treefalls are reported in Table 1. Table 2 contains the results of a Student's $t$-analysis applied to the density data in order to test for inequality of means between transects. The $t$ value was corrected for cases of unequal variances by adjusting the degrees of freedom (Sokal and Rohlf 1969:220). The results clearly show evidence of stratification along the length of treefalls for Cryosophila guagara. Individuals of this species $>60 \mathrm{~cm}$ tall occur most frequently in the first two transects at the root end of the treefall, least frequently in the fourth and fifth transects at the crown end, and at intermediate density in the third transect. Branching first occurs at or very near the third transect line in all five treefalls. The absence of C. guagara from the crown end of treefall clearings may be a result of mechanical damage to understory vegetation at the time of the treefall. The fallen canopy may also support an extensive cover of vines which block light penetration to ground level.

TABLE 2. Results of Student's $t$-tests for inequality of density means between transects. The * indicates cases of unequal variances where the comparisons were corrected by adjusting the degrees of freedom (Sokal and Rohlf 1969:220). NS indicates that the density means are not significantly different, i.e., that $p>0.05$. The numbers in the table are the one-tailed probabilities of observing a deviation as large or larger than the calculated $t$ value by chance

\begin{tabular}{|c|c|c|c|c|c|c|c|c|c|c|c|c|c|c|c|}
\hline \multirow{2}{*}{$\begin{array}{c}\text { Transect } \\
\text { no. }\end{array}$} & \multicolumn{5}{|c|}{$\begin{array}{c}\text { Cryosophila guagara } \\
\text { Transect no. }\end{array}$} & \multicolumn{5}{|c|}{$\begin{array}{c}\text { Neonicholsonia watsonii } \\
\text { Transect no. }\end{array}$} & \multicolumn{5}{|c|}{$\begin{array}{l}\text { Carludovica palmata } \\
\text { Transect no. }\end{array}$} \\
\hline & 1 & 2 & 3 & 4 & 5 & 1 & 2 & 3 & 4 & 5 & 1 & 2 & 3 & 4 & 5 \\
\hline $\begin{array}{l}1 \\
2 \\
3 \\
4 \\
5\end{array}$ & --- & NS & $\begin{array}{c}0.05 \\
0.05 \\
---\end{array}$ & $\begin{array}{l}0.008 \\
0.009 \\
\text { NS }\end{array}$ & $\begin{array}{l}0.001 \\
0.001 \\
0.02 \\
\text { NS } \\
\ldots\end{array}$ & $\ldots$ & NS & $\begin{array}{l}\text { NS } \\
\text { NS }\end{array}$ & $\begin{array}{l}\text { NS } \\
\text { NS } \\
\text { NS }\end{array}$ & $\begin{array}{l}\text { NS* } \\
\text { NS* } \\
\text { NS* } \\
\text { NS* } \\
\text {-.- }\end{array}$ & $\ldots$ & NS & $\begin{array}{l}\text { NS* } \\
\text { NS } \\
---\end{array}$ & $\begin{array}{l}\text { NS } \\
\text { NS } \\
\text { NS* }\end{array}$ & $\begin{array}{l}\text { NS } \\
\text { NS } \\
\text { NS } \\
\text { NS }^{*} \\
-\end{array}$ \\
\hline
\end{tabular}


TABLE 3. Areas $\left(\mathrm{m}^{2}\right)$ of the lightgaps from 5 treefalls. Treefalls 1,4 , and 5 resulted from the fall of single trees. Treefalls 2 and 3 each resulted from the fall of two adjacent trees

\begin{tabular}{cccc}
\hline $\begin{array}{c}\text { Treefall } \\
\text { no. }\end{array}$ & Trunk & Crown & Total \\
\hline 1 & 630 & 350 & 980 \\
2 & 180 & 130 & 310 \\
3 & 490 & 460 & 950 \\
4 & 480 & 440 & 920 \\
5 & 460 & 430 & 890 \\
Mean area & 448 & 362 & 810 \\
Median area & 480 & 430 & 920 \\
\hline
\end{tabular}

The data reported for Neonicholsonia watsonii and Carludovica palmata show no significant difference in the density of species between transects. The relatively high densities of Carludovica palmata in the first and fifth transects of the fourth and fifth treefalls suggest that this species may be restricted to the edge of clearings.

The areas of the treefall lightgaps are reported in Table 3. The values of Morisita's index for the adjacent forest are shown in Fig. 1. Cryosophila guagara individuals smaller than $2 \mathrm{~m}$ in height show evidence of maximal clumping at the quadrat size which is 2 units by 1 unit, or the equivalent of an area $18 \mathrm{~m}^{2}$. Neonicholsonia watsonii and Carludovica palmata also clump maximally at small quadrat sizes $\left(\leqslant 9 \mathrm{~m}^{2}\right)$. Factors determining these patterns remain unknown but may be related to the dispersal modes of these species. Cryosophila guagara individuals equal to or greater than $2 \mathrm{~m}$ in height clump maximally at the quadrat size which is 8 by 7 units, or $504 \mathrm{~m}^{2}$. This size corresponds closely to the mean size of the trunk portion of the lightgaps measured $\left(448 \mathrm{~m}^{2}\right)$. A standard $t$-test for comparing a single value to a sample mean (Sokal and Rohlf 1969) showed that the two values were not significantly different $(0.5<p<0.9)$. On the other hand, the areas at which maximal clumping occurs for Neonicholsonia watsonii $\left(\leqslant 9 \mathrm{~m}^{2}\right)$, Carludovica palmata $\left(\leqslant 9 \mathrm{~m}^{2}\right)$ and Cryosophila guagara $2 \mathrm{~m}\left(18 \mathrm{~m}^{2}\right)$ are significantly different from the mean area of the trunk end of treefalls $(p=0.05)$. The results suggest that the growth of the understory palm Cryosophila guagara is closely linked to the pattern of treefalls occurring in the forest.

Seedlings of Cryosophila guagara $<60 \mathrm{~cm}$ in height are present in great numbers on the floor of the closed canopy forest but seem to require the occurrence of a large canopy break to produce a woody trunk and preseumably to reproduce. Fully grown individuals can apparently maintain themselves for some unknown period of time after the

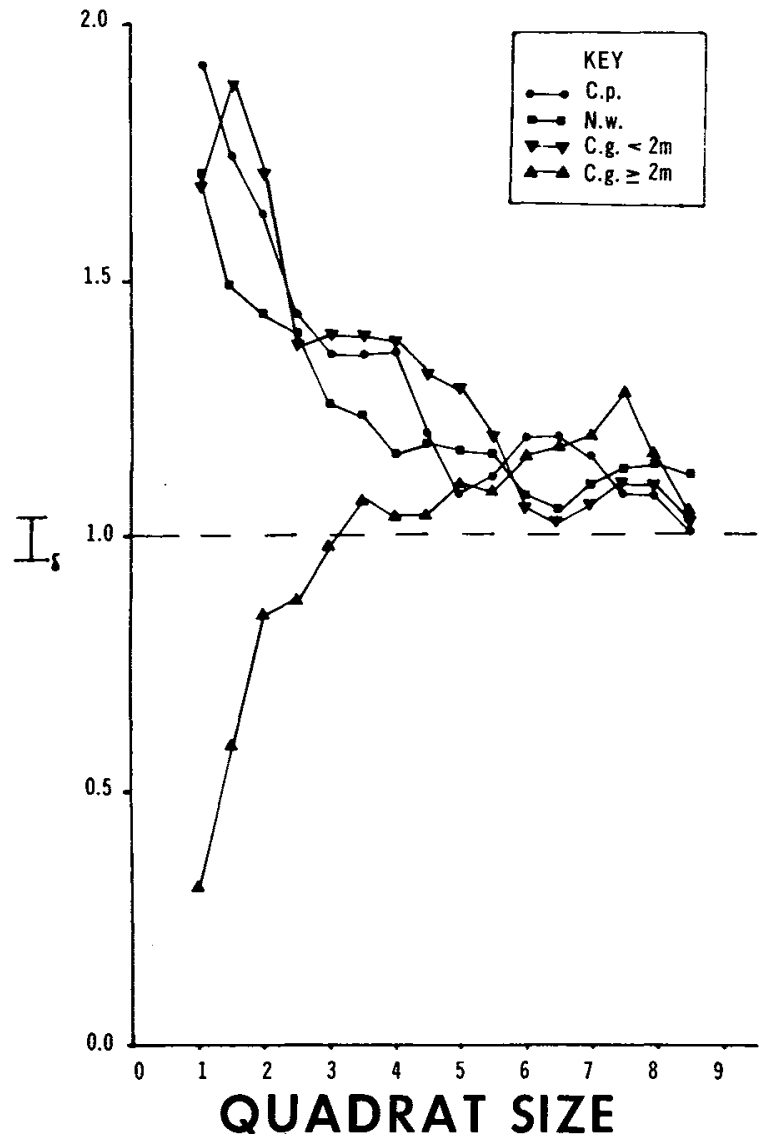

Fig. 1. Values of Morisita's index, $\boldsymbol{I}_{\delta}$, at different quadrat sizes, for Neonicholsonia watsonii, Carludovica palmata, Cryosophila guagara $<2 \mathrm{~m}$, and Cryosophila guagara $\geqslant 2 \mathrm{~m}$. Quadrat units are given as the length of the side of a square quadrat in $3 \mathrm{~m}$ units.

canopy closes over. The size distributions of Cryosophila guagara in treefall clearings and in the closed canopy plot support this hypothesis; Table 4 shows that the closed canopy plot contains numerous young trunkless individuals and a number of individuals greater than $8 \mathrm{~m}$ in height, while the treefall clearings contain a greater number of intermediate sizes.

The results of this study suggest that the pattern of fallen canopy trees and the growth requirements of a species of palm combine in a close-knit interaction which contributes to the mosaic pattern of the understory of a mature tropical forest. However, this mosaic pattern does not necessarily extend to the top canopy layers as in mature temperate forests (Williamson 1974). The pattern of individuals of any given species will depend on the number of adults which can occupy an average lightgap, or that part of a lightgap which is open to colonization by that species. The differentiation between the trunk and crown portions of treefalls suggests that 
TABle 4. Height (m) distributions of Cryosophila guagara individuals in the treefall area and in the closed canopy area. Actual numbers of individuals are shown in parentheses. The treefall and closedcanopy distributions are significantly different with $\chi^{2}=16.5$ and $6 \mathrm{df}(0.01<P<0.02)$

\begin{tabular}{|c|c|c|c|}
\hline \multirow[b]{2}{*}{$\begin{array}{l}\text { Height } \\
\text { class }\end{array}$} & \multicolumn{2}{|c|}{ Area } & \multirow{2}{*}{$\begin{array}{l}\text { Difference } \\
\text { (\% treefall } \\
\text { minus \% } \\
\text { closed } \\
\text { canopy) }\end{array}$} \\
\hline & $\begin{array}{c}\% \\
\text { treefall }\end{array}$ & $\begin{array}{c}\% \text { closed } \\
\text { canopy }\end{array}$ & \\
\hline $\begin{array}{c}<2 \\
2 \\
3 \\
4-5 \\
6-7 \\
8-9 \\
10-14\end{array}$ & $\begin{array}{r}40.6(43) \\
17.0(18) \\
11.3(12) \\
9.4(10) \\
10.4(11) \\
3.8(4) \\
7.5(8)\end{array}$ & $\begin{array}{c}54.5(90) \\
12.7(21) \\
9.7(16) \\
4.8(8) \\
2.4(4) \\
9.7(16) \\
6.1(9)\end{array}$ & $\begin{array}{l}-13.9 \\
+4.3 \\
+1.6 \\
+4.6 \\
+8.0 \\
+5.9 \\
+1.4\end{array}$ \\
\hline Total & 100.0 & 99.9 & +0.1 \\
\hline
\end{tabular}

succession processes in the two areas may be out of phase. Thus for any given species, the colonizable area of the gap may consist of the total gap or only some portion thereof. In species which have narrow crowns, several adult individuals may be able to occupy the colonizable area of a gap. In such cases a mosaic pattern of even-aged individuals of the species is likely to be observed. For example, Allen (1956) points out that species of Schizolobium and Vochysia, which are known to invade artificial clearings, sometimes form pure stands in lower montane rain forests. He postulates that these species occupy old clearings created by the fall of big canopy trees. In species which have wide crowns, only one adult may be able to colonize the average colonizable portion of a gap. As a result, these species would not exhibit a mosaic pattern of evenaged groups as there would be maximally one adult per colonizable lightgap area.
ACKNOWLEDGMENTS

We thank Robin Foster for stimulating much of our interest in this area, and Dennis Knight and Dan Janzen for their criticism of the manuscript. Special thanks to all participants in the Organization for Tropical Studies 73-1 field course.

\section{Literature Cited}

Allen, P. H. 1956. The rain forests of Golfo Dulce. University of Florida Press. 417 p.

Aubréville, A. 1938. La forêt coloniale: Les forêts de l'Afrique occidentale française. Ann. Acad. Sci. Colon., Paris 9:1-245.

Grieg-Smith, P. 1952. The use of random and contiguous quadrats in the study of the structure of plant communities. Ann. Bot. 16:293-316.

Harling, G. 1954. Taxonomical studies in the genus Carludovica. Acta Horti Bergiani 17:3.

Holdridge, L. R. 1971. Forests environments in tropical life zones. Pergamon Press, Elmsford, N.Y. 747 p.

Jones, E. W. 1945. The structure and reproduction of the virgin forest of the north temperate zone. New Phytol. 44:130-148.

Kershaw, K. A. 1963. Pattern in vegetation and its causality. Ecology 44:493-499.

Morisita, M. 1959. Measuring of the dispersion of individuals and analysis of the distributional patterns. Mem. Fac. Sci. Kyushu Univ., Ser. E Biol. 2:215-235.

Pielou, E. C. 1969. An introduction to mathematical ecology. Wiley-Interscience, New York. 286 p.

Richards, P. W. 1964. The tropical rain forest. 4th ed. Cambridge University Press. $450 \mathrm{p}$.

Schulz, J. P. 1960. Ecological studies on rain forest in northern Suriname. Verh. K. Ned. Akad. Wet., Afd. natuurk'd. Tweede Reeks 53:1-367.

Sokal, R. R., and F. J. Rohlf. 1969. Biometry, the principles and practice of statistics in biological research. W. H. Freeman, San Francisco. 776 p.

Steenis, C. G. G. J. van. 1956. Basic principles of rain forest sociology, p. 159-163. Proc. Kandy Symposium on Study of Tropical Vegetation. UNESCO, Paris.

Williamson, G. B. 1975. Pattern and seral composition in an old-growth beech-maple forest. Ecology 56:727-731. 